Pamiętnik Literacki 2020, 2, s. 153-166

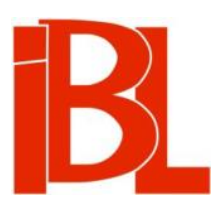

\title{
"Batrachomyomachia" w wersji Pawła Zaborowskiego. Uwagi wstępne
}

\author{
Jakub Zbądzki
}




\title{
„BATRACHOMYOMACHIA” W WERSJI PAWŁA ZABOROWSKIEGO UWAGI WSTEPNE*
}

\begin{abstract}
Batrachomyomachia - hellenistyczny poemat heroikomiczny - została napisana prawdopodobnie w I w. p.n.e. lub w I w. n.e. w Aleksandrii przez poetę, o którym wiemy jedynie to, że mógł się wychować w Imperium Rzymskim. Autor przeznaczył swój utwór dla wykształconych czytelników, obeznanych nie tylko z epiką archaiczną (i jej parodiami) oraz z epiką jemu współczesną, ale też z bajkami, komedią średnią i nową, a nawet ze scholiami do Homera. O wyjątkowości poematu świadczą zwłaszcza złożoność i nieoczywistość występujących w nim żartów - poszczególni mysi bądź żabi herosi mogą imitować w kolejnych partiach utworu zupełnie różnych bohaterów z Iliady i Odysei (np. raz Polifema, a raz Odyseusza) tudzież wymieniać się tymi rolami; ponadto zdarza się, że naśladuja postacie spoza wysokiego rejestru stylistycznego (takie jak komiczny smakosz) ${ }^{1}$.

Zadziwiające, ale Batrachomyomachia - która początkowo nie była chyba niczym więcej jak ciekawą zabawą literacką - w renesansie nieoczekiwanie stała się ważnym fenomenem dla kultury europejskiej. To pierwsze drukowane dzieło w języku greckim doczekało się do końca XVI w. ponad 100 wydań - oryginalnych i tłumaczonych. $Z$ lektury tekstów dołączanych do rozmaitych edycji: listów, epigramatów i innego typu wprowadzeń, autorstwa takich osób, jak Carlo Marsuppini, Joachim Vadian, Henricus Glareanus, François Tissard czy Hieronymus Osius, można wnioskować, że poemat zyskał wówczas odmienny charakter, niż miał w starożytności. Wciąż doceniano jego komizm i czytano go dla krotochwili, ale znacznie istotniejszy okazał się jego potencjał dydaktyczny. Batrachomyomachię na ogół uważano za młodzieńczą wprawkę słynnego Homera, dzięki której ów największy autorytet w dziedzinie poezji rozwinął swój styl i dojrzał do stworzenia wielkich eposów.
\end{abstract}

* Artykuł jest nieco zmienioną częścią pracy magisterskiej „Batrachomyomachia” Pseudo-Homera $w$ tłumaczeniu Pawła Zaborowskiego, napisanej pod kierunkiem prof. Jacka Sokolskiego (Uniwersytet Wrocławski, 2018).

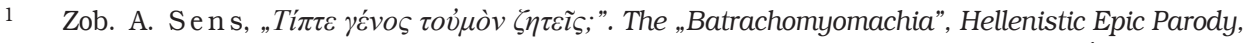
and Early Epic. W zb.: La Poésie épique grecque: métamorphoses d'un genre littéraire. Éd. F. M o ntanari, A. Rengakos. Vandoeuvres-Genève 2006, s. 225-226. - M. Hosty, The Mice of Ithaca: Homeric Models in the „Batrachomyomachia”. „Mnemosyne” t. 67 (2014), s. 1009-1011. 
Nierzadko twierdzono - czego przykładem jest chociażby Giovanni Marrasio ${ }^{2}$ - że musi to być właściwa metoda nauki pisania, skoro w postaci Iliady i Odysei przyniosła tak znakomite efekty. Dlatego też Osius czy Tissard zalecali lekturę Batrachomyomachii uczniom chcącym się nauczyć tworzenia poezji (i ewentualnie poznać nieco grekę). Stąd właśnie może wynikać lawinowy przyrost liczby tłumaczeń tego poematu.

Wśród XVI-wiecznych edycji dzieła, jeśli nie liczyć wydań tekstu greckiego, przeważają translacje łacińskie, $z$ których najpopularniejsze były: prozaiczny przekład interlinearny anonimowego autorstwa oraz wierszowany - Marsuppiniego, rozpowszechniany później także pod nazwiskiem Johannesa Reuchlina (w odniesieniu do tej translacji będziemy więc mówić o Pseudo-Reuchlinie; dodajmy, że właśnie jego wersję wydrukował Hieronim Wietor w Krakowie około 1522 roku). Pojawiły się wtedy również dwa tłumaczenia włoskie i jedno polskie; to ostatnie pióra Pawła Zaborowskiego ${ }^{3}$. Twórcy spolszczenia poświęcono dotąd mało uwagi, a byłoby rzeczą cenną ustalić, kim właściwie był, z jakich źródeł korzystał i jak się z nimi obszedł.

O Zaborowskim wiadomo bardzo niewiele. Wydaje się niemal pewne, że służył na dworze Mikołaja Krzysztofa Radziwiłła „Sierotki”, skoro to jemu zadedykował swój przekład. Prócz tłumaczenia Batrachomyomachii nie zachowało się po poecie prawie nic: Karol Estreicher starszy wspomina zaledwie o jednym epigramie z r. 1604, zawartym w księdze, na którą składają się wierszowane gratulacje dla Jana Tarnowskiego herbu Rola $z$ okazji objęcia funkcji arcybiskupa gnieźnieńskiego ${ }^{4}$. Tytuł księgi wskazuje, iż autorami tych drobnych utworów byli uczniowie kolegium jezuickiego w Kaliszu; jeśli więc Estreicher się nie pomylił - nazwisko poety nie należało przecież do niepowtarzalnych - Zaborowski musiał tam przebywać przez pewien czas. Nic więcej na ten temat nie wiemy. Rzekomo poeta miał umrzeć w 1621 r. jako minister toruńskiego zboru - tak przynajmniej podaja podręczniki akademickie. Ale jest to fałszywa informacja ${ }^{5}$.

2 G. Marrasi o, Hecatombe ad eloquentissimum virum Karolum Arretinum. W: Angelinetum and Other Poems. Transl. M. P. Ch atfi eld. Cambridge, Mass. - London 2016, s. 65, w. 87-88.

3 W wieku XVI ukazał się też łaciński przekład J. S i e m u s z o w s ki e g o, zatytułowany „Ranarum et murium pugna" Homeri (Bononiae 1568).

4 In primo felicissimo optatissimoque illustrissimi et reverendissimi patris et domini, domini Ioannis Tarnowski [...]. Ad suam Metropolitanam Ecclesiam Gnesnensem adventu gratulationes a studiosa iuventute Collegii Calissiensis Societatis Iesu factae. Kalisz 1604. Zob. K. E s t r e i c h e r, Bibliografia polska. T. 31. Wyd. S. Es tre i c her. Kraków 1891, s. 48-49.

5 Zob. Cz. Hernas, Barok. Wyd. 3. Warszawa 1978, s. 128. - J. Zi o m e k, Renesans. Wyd. 11. Warszawa 2012, s. 377. Źródłem błędu jest z pewnością hasło F. M. S obieszczań skiego (w: Encyklopedia powszechna Orgelbranda. T. 28. Warszawa 1868, s. 177), który przedstawił Zaborowskiego jako polemistę zwalczającego idee jezuitów i poparł to przykładem dzieł De missione sacerdotum in Ecclesia Romana [...], Ad nodum Gordium [...] oraz Ogień z woda [...]. Jak widać, przypisał Pawłowi życiorys innego Zaborowskiego - Jakuba. Na problem zwrócił uwage Es tre i c her (op. cit., t. 34, s. 41). Zauważył on, że L. Ć wi k li ńs ki (Nowy przekład Homerowskiej „Batrachomyomachii” w porównaniu z dawniejszymi. „Przewodnik Naukowy i Literacki. Dodatek do "Gazety Lwowskiej"” 1884, nr 12, z. 4) myli ze sobą obu Zaborowskich, opierając się na wiedzy zaczerpniętej właśnie $z$ Orgelbranda - spostrzeżenie to zostało jednak przeoczone przez późniejszych badaczy. 
Jedyne znane nam dzieło Zaborowskiego, Batrachomyomachia, albo Żabomysza wojna, zostało wydane w 1588 r. w Krakowie, najprawdopodobniej w drukarni Jakuba Siebeneichera ${ }^{6}$. Do dziś przetrwały dwa egzemplarze owej edycji: kórnicki i ossoliński ${ }^{7}$. Tłumaczenie poematu na język polski poprzedzają krótkie utwory Zaborowskiego. Pierwszy, Na herb Jego M[o]ści Pana Mikołaja Krzysztofa RadziwiŁa, na Ołykach i Nieświeżu ksiązęcia etc., to dość typowy stemmat: dedykowany „Sierotce” panegiryk, w którym poeta skupia się na znaczeniu widocznego w herbie Radziwiłłów orła. Wiadomo, że wraz z tytułem księcia symbol ten został nadany przez cesarza Karola V ojcu „Sierotki” - Mikołajowi Radziwiłłowi Czarnemu. Zaborowski nie uwzględnia jednak historycznego wymiaru wydarzenia i stara się zmitologizować dzieje rodu, przydać mu czci, a także zapewnić o jego świetlanej przyszłości, twierdząc, iż taki właśnie znak jest czytelnym świadectwem przychylności Jowisza - dowodem tego mają być dawne sukcesy wojsk rzymskich, niosących orła na swoich sztandarach. W drugim tekście, również dedykowanym „Sierotce” (Oświeconemu i Jaśnie Wielmożnemu Panu a Panu Mikołajowi Krzysztofowi Radziwiłowi, na Ołyce i Nieświeżu książęciu etc., etc., Panu memu miłościwemu), poeta podejmuje klasyczny topos wejścia na Parnas ${ }^{8}$. Pozostając w duchu renesansowym, kreśli wizję, w której Kaliope i Talia (muzy patronujące - odpowiednio - poezji epickiej i komedii, a zatem $z$ pewnością sprzyjające też twórcom heroikomiki ${ }^{9}$ ) wręczaja mu różdżkę (antyczny symbol umiejętności poetyckich, znany m.in. z idylli Teokryta Dożynki) oraz puchar wody zaczerpniętej ze źródła bogiń. Zaborowski zdaje sobie sprawę, że jego wiersz jest jedynie drobiazgiem literackim i że na więcej jeszcze go nie stać. Świadczy o tym odpowiedź muz, które pouczają go, iż zdolność do stworzenia czegoś większego - jak można się domyślać: eposu - wymaga dojrzałości, osiaganej przez poetów dopiero z czasem. Poprzez taką narrację Zaborowski wpisuje się w typowy w renesansie tok myślenia: tłumaczenie poematu heroikomicznego nie stanowi dla niego celu ostatecznego, lecz zaledwie ćwiczenie.

Naszego poetę łączy z poprzednikami o wiele więcej niż sama intencja stworzenia przekładu. Przed rozwinięciem owej kwestii należałoby wszakże zapytać, na kim właściwie się on wzorował - stwierdzenie tego nie jest rzeczą prostą. Pierwszy zajął się tym Ludwik Ćwikliński, który zauważył, że translacja Zaborowskiego znacząco różni się od innych. Jako najbardziej oczywistą przyczynę wskazał nader swobodne podejście poety do procesu tłumaczenia, przejawiające się usuwaniem całych passusów greckiego oryginału i dowolnym dodawaniem własnych fragmen-

6 Zob. A. Wój c i k, Bibliografia druków Jakuba Siebeneichera (1583-1604). Przyczynek do przyszłej edycji zasobu drukarskiego. W zb.: Staropolska ikonografia a nauki pomocnicze historii. Materiały z II Ogólnopolskiej Studencko-Doktoranckiej Konferencji Nauk Pomocniczych Historii w Krakowie, 7-8 maja 2015 r. Kraków 2016, s. 170.

7 Bibl. Kórnicka PAN, Cim.Qu.2645 - zob. na stronie: http://www.wbc.poznan.pl/dlibra/docmetadata?id=298046 (data dostępu: 30 XI 2018); Bibl. Ossolineum we Wrocławiu, XVI.Qu.2416 - zob. na stronie: http://www.dbc.wroc.pl/dlibra/docmetadata?id=10478 (data dostępu: 30 XI 2018).

8 Zob. E. Sarnows ka-Te m eriu s z, Droga na Parnas. Problemy staropolskiej wiedzy o poezji. Wrocław 1974.

9 Autorzy poematów heroikomicznych chętnie powoływali się na Talię. Przykładem może być pierwszy wers utworu Culex z Appendix Vergiliana (w: Vir g i 1, Aeneid: books 7-12. - Appendix Vergiliana. Transl. H. R. F a irclough. Rev. G. P. Goold. Cambridge, Mass., 2001, s. 404). 
tów. Według niego Zaborowski korzystał z odmiennych źródeł niż późniejsi tłumacze, co pokazuja już pojedyncze, dość zaskakujące lekcje, które mogłyby zresztą posłużyć nawet do ustalenia pierwotnego brzmienia tekstu, zapewne zepsutego w toku dziejów ${ }^{10}$. Obecnie - po przeszło 130 latach od publikacji Ćwiklińskiego, gdy zdążyło wyjść kilka wydań krytycznych Batrachomyomachii ${ }^{11}$, a dobrodziejstwa technologii niezwykle ułatwiły porównywanie rękopisów sprzed wieków - wiemy, że Ćwikliński bardzo się pomylił. To prawda, że Zaborowski zmienił w tekście sporo partii, ale nie był on wierny wobec źródeł w takim stopniu, jak przypuszczał badacz, poza tym edycje poematu $z$ XVIII i XIX w. nie są aż tak złe, jak sądził. Choć wciąż trwają spory co do oryginalnego brzmienia tekstu, zwłaszcza dotyczące zakresu interpolacji, widać jasno, że wbrew opinii Ćwiklińskiego staropolski poeta nie polegał jedynie na grece (mimo iz korzystał ze wspomnianej wersji interlinearnej, jak później zobaczymy), co byłoby zresztą zgodne $z$ faktem, że nawet w renesansie znajomością owego języka mogli się pochwalić tylko nieliczni humaniści. Jeśli porównamy wszystkie łacińskie tłumaczenia Batrachomyomachii opublikowane do r. 1588, okaże się, że żadne z nich nie osiągnęło doskonałej wierności wobec oryginału - głównie ze względu na pewne problemy interpretacyjne, dotyczące znaczenia greckich słów. Efektem porównania będzie stwierdzenie drobnych różnic, one zaś okażą się niezwykle pomocne, pozwolą bowiem prześledzić, które warianty Zaborowski wybierał. Znajdujemy u niego zarówno te pojawiające się wyłącznie w przekładach, jak i te występujące także w tekście greckim - w drugim wypadku zawsze jednak oddane po łacinie bardzo dokładnie, co pozwala zastosować brzytwę Ockhama i odrzucić przypuszczenie, że poeta władał językiem dość rzadkim nawet wśród humanistów. Pozostaje zatem ustalić, jakimi tłumaczeniami łacińskimi Zaborowski mógł dysponować.

W wieku XVI ukazało się ponad 100 takich wydań $^{12}$, lecz opierały się one zaledwie na kilku przekładach, czego dowiodła Janina Czerniatowicz. Badaczka podała 6 wersji metrycznych (Marsuppiniego, Aedicolliusa, Pseudo-Reuchlina, Lemniusa, Osiusa i Siemuszowskiego) oraz jedna prozaiczną, która przypisała Aldowi Manuziowi ${ }^{13}$ (w rzeczywistości jest to anonimowy przekład interlinearny, który po dokonaniu pomniejszych zmian był podpisywany kolejnymi nazwiskami ${ }^{14}$;

10 Ćwiklińs ki, op. cit., s. 383. Badacz dysponował wszystkimi istniejącymi w jego czasach polskimi przekładami, tj. J. I. Przybylskiego (1789), B. Kicińskiego (1815) i - najświeższym - R. Palmsteina (1883), który zainspirował go do napisania artykułu. Potem powstały już tylko tłumaczenia I. Wieniewskiego (1929) i W. Appela (1993, 2007).

11 Zob. np. Batrachomyomachia. W zb.: Homeric Hymns. - Homeric Apocrypha. - Lives of Homer. Ed., transl. M. L. W e s t. Cambridge, Mass. - London 2003. Cytaty z tej edycji lokalizujemy za pomocą skrótu B oraz numerów stronicy i wersu.

12 Informacje o wszystkich tych edycjach znajdują się w bazie Universal Short Title Catalogue. Zob. na stronie: https://www.ustc.ac.uk (data dostępu: 6 VI 2020).

13 J. Czerniatow ic z, Recepcja poezji greckiej $w$ Polsce $w$ XVI-XVII wieku. Wrocław 1966, s. 16.

14 Łatwo to stwierdzić, gdy zestawi się ze sobą różne tłumaczenia. Oto pierwsze trzy wersy przekładu interlinearnego i przekładu Manuzia:

- „Incipiens primum Musarum chorum ex Helicone / Venire in meum cor opto causa cantu / quem nuper in libellis meis super genibus posui";

- „Incipiens primum Musarum coetum ex Helicone / Venire in meum cor supplico gratia cantus / quem nuper in libellis meis super genua posui". 
Manuzio dokonał co najwyżej pewnej korekty przekładu). Z Batrachomyomachia mierzyli się też tacy tłumacze, jak Tilmann Conradi ${ }^{15}$ czy Joachim Münsinger. Czerniatowicz nie odnotowała ich jednak, ale chyba nie $z$ powodu przeoczenia, tylko w związku z przekonaniem, iż tłumacze na ogół nie korzystają z mało popularnych wersji - można tak przypuszczać na podstawie odrzucenia przez nią jako źródła Zaborowskiego przekładu Siemuszowskiego; badaczka uzasadniała swoje zdanie tym, że w Rzeczypospolitej było mało egzemplarzy owego tekstu i że liczy on aż dwa razy więcej wersów niż oryginał i przez to niewiele go przypomina. Znacznie silniejszy jest jej drugi argument. Przy dowodzeniu popularności tekstu należy zachować ostrożność.

Zaborowski korzystał również z rzadszych, dotąd nie uwzględnianych źródeł. Wyjaśnić to może drobiazgowa analiza porównawcza tekstów, której do tej pory nie dokonano ${ }^{16}$, a więc zestawienie ze sobą różnych partii $z$ łacińskich wersji Marsuppiniego, Pseudo-Reuchlina, Aedicolliusa, Münsingera, Lemniusa i Osiusa oraz poszczególnych lekcji, wyjaśnienie przyczyn, dla których zachodzą różnice (są to wspomniane problemy interpretacyjne), i wskazanie, z których wersji Zaborowski korzystał. Takie badanie musi się ograniczyć siłą rzeczy do wybranych passusów (porównanie całości przerastałoby objętość tego artykułu). Dla jasności wywodu zajmiemy się tutaj tylko pierwszą połową utworu, ponieważ dalsza część wersji Zaborowskiego jest już bardzo swobodna przeróbką i zasługuje na kilka osobnych akapitów omawiających nowości wprowadzone przez poetę ${ }^{17}$.

Tilmann Conradi (Thiloninus Philymnus Syasticanus; ok. 1485 - 1522) - humanista $z$ Getyngi, poeta, prawnik; wykładał literaturę grecką na uniwersytecie w Erfurcie, uczył łaciny i greki w Wittenberdze. Jego przekład Batrachomyomachii nie był szeroko rozpowszechniony i szybko stał się wielką rzadkością, tak że dziś nawet już nim nie dysponujemy.

16 C z e rnia t ow i c z, op. cit., s. 18. Badaczka poprzestała na przyznaniu, iż nie wiadomo, czy Zaborowski korzystał z tekstu greckiego. Poruszyła jedynie kwestię źródeł Siemuszowskiego, stwierdzając, że posługiwał się on najpewniej przekładem interlinearnym, ponieważ w prooemium napisał: „Arma [...] et turmae [...] concurrere cano, numeris intacta priorum [Oręż $\langle\ldots\rangle$ i zastępy $\langle\ldots\rangle$ spieszę opiewać, wierszem poetów dotąd nie tknięte]". Dziwiła się wprawdzie, że poeta mógłby uznać siebie za twórce pierwszego metrycznego tłumaczenia Batrachomyomachii, skoro tyle ich wszędzie krążyło, ale w dobrej wierze uznała, że mówi on prawdę i musiał się zetknąc wyłącznie $z$ wersją prozaiczną. Trudno wszakże zaufać Siemuszowskiemu, mając w pamięci innych twórców, którzy opisywali siebie wbrew rzeczywistości jako pierwszych w danej dziedzinie, co wynika oczywiście z dumy (chyba najsłynniejszym tego przykładem jest Horacy, chwalący się w pieśni III 30 przeniesieniem na grunt rzymski miar eolskich, choć wszyscy wiedzieli, że wcześniej podobne i nader udane próby czynił Katullus). W takiej sytuacji należałoby ponownie zbadać źródła Siemuszowskiego. Krytyczna analiza jego przekładu z pewnością wymaga jednak osobnej pracy.

Cytaty z poszczególnych tłumaczeń lokalizujemy za pomocą skrótów: $\mathrm{HO}=\mathrm{H}$. O si u s, „Pugna ranarum et murium” Homeri. Ratisponae 1566. $-\mathrm{JM}=\mathrm{J}$. M ü n s in ge r, Homeri „Batrachomyomachia". Friburgi Brisgoviae 1547. - PZ = P. Za b o r ow ski, Batrachomyomachia, albo Żabomysza wojna. Kraków 1588. - SA = „Batrachomyomachia” Homeri. Transl. S. A e d i c olli u s. Daventriae 1528. $-\mathrm{SC}=$ Homeri opera Graecolatina . Transl. S. C hât e illon. Basileae 1561. $-\mathrm{SL}=\mathrm{S}$. Le mniu s, „Odysseae” Homeri libri XXIIII [...] accessit et „Batrachomyomachia” [...]. Basileae 1549. $\mathrm{W}$ analizie porównawczej wykorzystaliśmy ponadto wersje C. Mars u p pini e go (Homeri poetae „Batrachomiomachia”. 〈Wenecja [?], ok. 1475〉) i P s e u d o-Re u c hl in a (Homeri „Batrachomyomachia". I. Capnione Phorcensi metaphraste. Viennae 1510). W przypadku cytowań odnoszacych się do anonimowej wersji interlinearnej (SC) skorzystaliśmy z jej kopii z naniesionymi nielicznymi zmianami autorstwa Châteillona (porównywalnej z wersją Manuzia), a to ze względu 
Pewne odstępstwa od oryginału, pozwalające na wysunięcie hipotezy o źródłach Zaborowskiego, widać już w inwokacji. Niemal wszystkie wersje łacińskie zawierają w tym miejscu obraz pisania utworu na kolanach. Brak go u Siemuszowskiego, a także u Münsingera, który pozwolił sobie na drobną zmianę, używając dość neutralnego zwrotu „contexere chartis” (JM, s. 23, w. 2). Zaborowski posłużył się sformułowaniem o takim samym znaczeniu: „w kartę kładę” (PZ, s. 9, w. 3). Każe to zwrócić baczniejszą uwagę na niemieckiego tłumacza, którego pominęła Czerniatowicz. Istotny w inwokacji jest też obraz boga wojny - Aresa bądź Marsa. Znajduje się on we wszystkich tekstach, tylko nie w wersjach Marsuppiniego, Pseudo-Reuchlina i Aedicolliusa. To pierwszy ślad, który wskazuje, że Zaborowski raczej nie miał w ręku tych trzech przekładów wierszowanych.

Do identycznych wniosków poprowadzi zawiązanie akcji, gdzie występuje mysz uciekająca przed stworzeniem zwanym przez Greków „galéēs” (B, s. 266, w. 9). Takim mianem określano w języku starogreckim zwierzęta łasicowate, hodowane w celu odławiania myszy: tchórza, kunę, fretkę, a zwłaszcza łasicę. U Zaborowskiego pojawia sie jednak kot. To prawie na pewno nie jego pomysł - o tym dobrze znanym zwierzęciu mówią bowiem niemal wszystkie przekłady łacińskie. Można przypuszczać, że ówcześni tłumacze wybierali na ogół bliższy ich realiom wariant, ponieważ słowo "galéés” stopniowo zaczęło w grece oznaczać także kota ${ }^{18}$. Do wyjątków należą teksty Marsuppiniego i Pseudo-Reuchlina. To kolejny dowód na to, iż Zaborowski nie korzystał $z$ tych wersji. Trzeba też odnotować, że Münsinger użył identycznego epitetu co polski poeta, nazywający kota chciwym: „Mus fugiens avidi non parva pericula cati [Mysz uciekająca przed niemałym niebezpieczeństwem w postaci chciwego kotal" (JM, s. 23, w. 9).

Nieco dalszy passus, w którym została przedstawiona podróż myszy na grzbiecie króla żab, pozwala chyba ostatecznie odrzucić możliwość, iż Zaborowski posiłkował się wersja Marsuppiniego czy Pseudo-Reuchlina. Tylko w tych tekstach bowiem słowa myszy porównującej sytuację do mitu o Dzeusie-Jowiszu i Europie są wplecione w narrację. Reszta przekładów je wyodrębnia - i tak samo też czyni polski poeta.

Szybko okazuje się jednak, że trzeba skorygować początkowe domysły, czyli uznanie Münsingera za wyłączne źródło Zaborowskiego. Wątpliwości wynikają $\mathrm{z}$ analizy porównawczej opisu ceremoniału przedstawiania się, podczas którego mysz wspomina m.in. swój dom. W wersji greckiej tym miejscem jest „kalýbē [chatka, szałas]" (B, s. 266, w. 30). Zaborowski pisze z kolei o dębie (PZ, s. 2, w. 44), ale tylko w pierwszej chwili wydaje się to bezpodstawną innowacją. Większość prze-

na utrudniony dostęp do jedynego egzemplarza pierwodruku, przechowywanego w John Rylands Library w Manchesterze, i do jego skorygowanego wznowienia, wydanego w Bazylei w 1518 roku. Jeśli cytowana edycja nie ma paginacji, w nawiasach kątowych podajemy numery stronic liczone od początku poematu, pomijając tym samym teksty wstępne. Wersy zostały ponumerowane dla każdej stronicy z osobna ( $\mathrm{z}$ wyjątkiem wersji Zaborowskiego, dla której przyjęto numerację ciagła), przy czym w zasadnych wypadkach podano numery liczone od dołu stronicy (wskazuje na to skrót „d.”, umieszczony po numerze wersu).

18 Proces ten rozpoczął się w IV w. n.e., i to mimo istnienia osobnego wyrazu na to bliskie nam zwierzę - „aíluros” - a stało się tak prawdopodobnie dlatego, że po importowaniu kot zaczął pełnić identyczną funkcję co łasicowate. 
kładów łacińskich nie wyjaśni jej zastosowania - Marsuppini i Pseudo-Reuchlin o domu nic nie mówią, Aedicollius tłumaczy w zgodzie $\mathrm{z}$ oryginałem: „sub tectis habitans [mieszkając pod dachem]” (SA, s. $\langle 2\rangle$, w. 10); tak samo Lemnius: „sub tuguri tecto [pod dachem chaty]” (SL, s. 677, w. 13), i Münsinger: „progenuit vero in tuguri me [urodziła mnie w chacie]" (JM, s. 24, w. 16). Droga od chaty do dębu może jednak stać się zrozumiała, jeśli wprowadzimy do porównań przekład interlinearny. Mysz opowiada tam bardzo ogólnie o czymś, co jest drewniane: "genuit autem in lignario me [urodziła mnie w drewnianym 〈domu〉]" (SC, s. 227, w. 11). Dla Zaborowskiego mogło się to odnosić nie tyle do chaty wykonanej $z$ drewna, ile do samego drzewa. Zdaje się, że niektórzy późniejsi tłumacze też mieli trudności $z$ interpretacją, wynikające $z$ posłużenia się enigmatyczną w tym miejscu wersją prozaiczna - jak Osius, który pisał o drewnianym koszyku (,lignea cista”, HO, s. 2, w. 4). Musimy zatem uwzględnić ten tekst jako kolejne potencjalne źródło polskiego poety i sprawdzić to przypuszczenie.

Ku stwierdzeniu, że Zaborowski mógł korzystać również z wersji interlinearnej, będzie nas kierować także imię, jakim król żab nazywa najwyższego z bogów. W oryginale użyto słowa „Kroníōn [Kronida]” (B, s. 268, w. 59), tak więc wydawałoby się, że tłumacze będą oddawać to jednakowo. Ale w przekładach widać dwie różne ścieżki. Część translatorów wybiera łacińską formę „Saturnius” (tak czynią Marsuppini, Pseudo-Reuchlin, Münsinger i Osius), a część - prostsze określenia: w wersji interlinearnej jest to jeszcze „Saturnius Jupiter” (SC, s. 227, w. 40), u Aedicolliusa już po prostu „Juppiter” (SA, s. 〈3〉, w. 15), u Lemniusa nawet bardziej ogólnie: „Deus” (SL, s. 679, w. 1). Zaborowski opowiada wyłącznie o Jowiszu, zatem albo sam upraszcza, albo korzysta $z$ któregoś z przekładów zawierających poręczniejsze określenie, zapewne $\mathrm{z}$ wersji interlinearnej.

Jeszcze silniejszą przesłankę na rzecz przyjęcia przedstawionego stwierdzenia stanowi opis tego, jak król żab uniknął śmierci. U Zaborowskiego czytamy: „Skrzeczołóg z sidła Parki czarnej uszedł” (PZ, s. 4, w. 121). Prócz metafory pułapki zgadza się to z przekładem prozaicznym: „evitavit Parcam nigram” (SC, s. 228, w. 11). Trochę dalej jest Lemnius, opowiadający o umknięciu przed czarnymi nićmi sióstr Parek: „Parcarum evasit nigrantia fila sororum” (SL, s. 681, w. 15). Znacznie mniej wierni greckiej wersji są natomiast Aedicollius, używający ogólnego pojęcia losu, przed którym płaz miał się uchronić: „vellet praesens evadere fatum” (SA, s. $\langle 4\rangle$, w. 5 d.), a także Münsinger i Osius, piszący o gorzkiej lub ciemnej, ponurej śmierci: „mortemque acerbam” (JM, s. 27, w. 14), ,atram mortem” (HO, s. 3, w. 5 d.).

Jak widać, przyjrzenie się wariantom pozwala przynajmniej zawęzić krag poszukiwań. Na podstawie podanych przykładów da się spostrzec, że Zaborowski w pewnych miejscach jest szczególnie bliski tłumaczeniu prozaicznemu, ale widzieliśmy też, że w innych zdawał się korzystać z przekładu niemieckiego poety. Pozostaje określić, czy sięgnął tylko po jedną $\mathrm{z}$ wersji (a podobieństwo do drugiej można wyjaśnić innym sposobem), czy po obie. Należy zatem porównać je ze sobą. Zaznaczmy, że miejscami są one do siebie dość zbliżone - identyczne frazy występują nawet $\mathrm{w}$ samym prooemium - i nie wynika to $\mathrm{z}$ posługiwania się przez autorów tekstem greckim. Ponieważ u Münsingera występują na marginesach niemal identyczne etymologie imion co w przekładzie interlinearnym, $\mathrm{z}$ dużym prawdopodobieństwem można sądzić, że musiał on po niego sięgnąć. Na szczęście Münsinger 
raczej tylko inspirował się wersją prozaiczną, niż ją kopiował, więc różnice między nimi na pewno pozwolą wykazać, $z$ czego mógł korzystać Zaborowski.

W poczatkowych partiach tekstu polskiego poety znajduja się jeszcze pewne formuły, które - jak się wydaje - są zaczerpnięte z tłumaczenia poetyckiego. Kiedy w wersji prozaicznej król żab mówi o swoim panowaniu dość lakonicznie: „per lacum / Color, ranarum dux dies omnes [czczą mnie w jeziorze - wodza żab po wsze dni]” (SC, s. 226, w. 53-54), Münsinger nieco to rozszerza: „per stagna lacusque / Qui color et ranarum ingens cui supplicat orbis [czczą mnie stawy i bagna, a korzy się przede mna wielki krag żab]” (JM, s. 24, w. 2-3). Zaborowski pisze z kolei: ,jeziorom słynę wszystkim, a te czczą mię brzegi / i rade pod me nogi dają swe okręgi” (PZ, s. 1, w. 27-28). Chociaż ze źródłem poczyna sobie swobodnie, widać, że wspomniane tu „okręgi” zaczerpnął najpewniej z przekładu wierszowanego.

W dalszych partiach to jednak ślady inspiracji przekładem interlinearnym stają się wyraźniejsze. W scenie przedstawiającej podróż myszy na grzbiecie żaby (choć znacznie przerobionej i skróconej przez Zaborowskiego) pojawia się fraza będąca niemal kalką $\mathrm{z}$ wersji prozaicznej, ,z płaczem na nietrzebna skruchę utyskuje” (PZ, s. 4, w. 94) - z łacińskiego: „multum lacrimans / Inutilem paenitetiam accusabat" (SC, s. 227, w. 49-50), co z mniejszym prawdopodobieństwem mogło zostać zapożyczone od Münsingera, piszącego w tym miejscu nieco ogólniej: „effundit lachrymas, incusat et ipsum / Se frustra [lał łzy i oskarżał siebie na darmo]" (JM, s. 26, w. 5-6 d.). Tak samo słowa: „Żem utracił trzech synów” (PZ, s. 6, w. 166), brzmia zupełnie jak wierny przekład tekstu prozaicznego: „treis filios perdidi” (SC, s. 228, w. 37), nie zaś archaizowanej w tym miejscu wersji wierszowanej: „privatus inique / Iam gnatis tribus [niesprawiedliwie pozbawiony już trzech potomków]" (JM, s. 29, w. 5-6). Również kiedy Zaborowski opisuje przybycie posła myszy, który „wieść dając smutną, strasznej opowiada wojny” (PZ, s. 7, w. 197), widać ślad epitetu występującego w prozie: „nuncians bellimalam famam [głosząc wieść o niosacej zło wojnie]" (SC, s. 229, w. 8), a nie pojawiającego się w uproszczonym przekładzie Münsingera: „indicens bellum [zapowiadając wojnel” (JM, s. 30, w. 9). Jeszcze lepszym przykładem jest opis odejścia posła i efektu jego przemowy. Tłumaczenie Zaborowskiego: „tak rzekłszy, odszedł, a głos wnet padszy im w uszy” (PZ, s. 7, w. 205), jest właściwie kalką $\mathrm{z}$ wersji prozaicznej: „sic locutus disparuit, sermo autem in aures murium / Ingrediens" (SC, s. 229, w. 14-15), Münsinger z kolei bardzo zwięźle pisze tylko o ogłoszeniu wojny: „sic memorans bellum prenunciat [to wspominając, ogłasza wojnę]" (JM, s. 30, w. 9 d.), a nic o odejściu i mowie trafiającej do uszu. I ostatni przykład, odwrotny w stosunku do cytowanej mowy króla żab na zgromadzeniu - Münsinger pozwala sobie na daleką od oryginału znaczną ozdobność: „verum et prudens nec inutile vobis / Consilium dabo [przedstawię wam pomysł rzetelny, mądry i niebezużyteczny]" (JM, s. 31, w. 1-2), przekład prozaiczny jest za to dość surowy: „etenim ego dico ut mihi videtur esse optimum [a ja powiem, co jest najlepsze, jak mi się widzi]" (SC, s. 229, w. 22), i to do niego z pewnością nawiązuje Zaborowski, pisząc: „tak jako mi się widzi, dobrze by" (PZ, s. 15, w. 215).

Z przedstawionego porównania widać wyraźnie, że Zaborowski korzystał z dwóch wersji łacińskich: anonimowej napisanej prozą i wierszowanej Münsingera. Sięgał po nie równolegle, wybierając warianty, które mu odpowiadały, a przynajmniej 
czynił tak do pewnego miejsca, ponieważ dalsza część utworu - jak zauważyliśmy jest coraz swobodniejszą przeróbką.

Skoro mamy już wyobrażenie o tym, z jakich źródeł korzystał Zaborowski, pora ustalić, czym kierował się w swoim tłumaczeniu. Jak wiemy, nie starał się on przełożyć poematu wiernie - usuwał ważne dla oryginału elementy, sporo też dodawał od siebie. Chociaż w jego postępowaniu trudno dopatrzyć się konsekwentnie stosowanej strategii translatorskiej, można wskazać przynajmniej kilka tendencji dominujących w jego pracy.

Pierwsze wersy tekstu dość dobrze pokazują ogólny zamysł Zaborowskiego: rzetelne oddanie większości istotnych elementów cechujących poemat heroikomiczny. Mamy zatem wezwanie muz, przedstawienie tematu i komiczne powiększenie rangi wydarzenia, a prócz tego jeszcze mały dodatek: odwołanie się do Bellony, rzymskiej bogini wojny, popularnej w renesansie. Brakuje jedynie przetłumaczenia motywu spisania utworu na kolanach, zaczerpniętego przez autora oryginału z Aitiów. Zaborowski użył formuły „w kartę kładę” i uczynił to na pewno świadomie - korzystał przecież co najmniej z dwóch przekładów zawierających wspomniane nawiązanie. Jest bardzo prawdopodobne, że było ono dla niego niezrozumiałe, i nie ma w tym nic dziwnego, skoro w renesansie nie znano tego dzieła Kallimacha ${ }^{19}$. Dlaczego w takim razie inni tłumacze, choć również nie zdawali sobie sprawy ze znaczenia motywu, byli wierni oryginałowi i niczego nie zmieniali? Najpewniej zależało im na dokładnym oddaniu starożytnych realiów. Filip Melanchton, omawiając w swoim komentarzu do Batrachomyomachii pierwsze wersy poematu, powołał się na scholion, który miał dowodzić, że w starożytności pisało się na kolanach ${ }^{20}$ i ścisłe podejście do przekładu nakazywało zachować ten element. Jednakże polski poeta, jak się zdaje, chciał utwór nieco uwspółcześnić. Jeśli przyjmiemy takie założenie, rozwiąże to przy okazji pozostałe kwestie, na pierwszy rzut oka zupełnie niezrozumiałe.

Z pewnością zadziwiać muszą opisy zbrojenia się przez myszy i żaby. W pierwszym wypadku Zaborowski zmienia cały rynsztunek (pomija nagolenniki z bobu, skórzany pancerz zastępuje zbroja z grochu oraz kaftanem $z$ pierza i siana, tarczę z lampy - skórką chleba, włócznię z igły - źdźbłem, hełm z grochu - leszczyna), w dodatku usuwa najbardziej komiczne elementy, czyli formułę „spiżowe dzieło Aresa”, odnoszącą się do włóczni, i informację, że myszy zdarły skórę na pancerz z łasicy czy też kota ${ }^{21}$. Jest to zarazem nawiązanie do wcześniejszych bajek o zwierzętach i jakby parodia Heraklesa pokonującego lwa nemejskiego. Opis uzbrojenia żab stanowi zaś bardzo precyzyjną kopię źródeł Zaborowskiego (kolejno: nagolenniki ze ślazu - ślaz wokół bioder; zbroja z liści buraka - zielony kaftan; tarcza

Aitia zaginęły około XIII stulecia. Żyjący w drugiej połowie XIV w. humanista A. Poliziano odtworzył ogólny obraz tego dzieła, a dopiero w 1577 r. pojawiła się pierwsza edycja zachowanych utworów i fragmentów autorstwa Kallimacha, przygotowana przez H. Estienne’a młodszego; nie zawierała ona jednak żadnego passusu z Aitiów. Zob. A. Hard er, wstęp w: Callim a chu s, Aetia. Ed. A. Hard e r. T. 1: Introduction, Text, and Translation. Oxford 2012, s. 72.

20 Zob. L. Ly ciu s, Batrachomyomachia. Homeri poema [...]. Lipsiae 1566, s. 38.

21 Warto zwrócić uwagę na wspólny element w heroikomice oraz w literaturze sowizdrzalskiej, jakim jest komiczne przedstawienie uzbrojenia - z tego też mógł czerpać Zaborowski. 
z liści kapusty, miecz z trzciny i hełm ze skorupki powtarzają się już dokładnie). Spodziewalibyśmy się modyfikacji obu passusów albo pozostawienia ich w starej formie, a nie zmiany tylko jednego - lecz i dla tej decyzji można znaleźć wyjaśnienie. Myszy z pewnością są zwierzętami, $\mathrm{z}$ którymi ludzie mieli w historii o wiele częstszy kontakt niż z żabami, dlatego wiedzieli o nich znacznie więcej. Zaborowskiego mogło razić wyposażenie niezbyt przystające do wyobrażeń obowiązujących w jego czasach, więc na podstawie doświadczenia wybrał on elementy z polskiej, wiejskiej rzeczywistości. Żabami mógł już się nie przejmować, niezbyt je znając, stąd powielił opis mimo występowania w nim rzeczy, z którymi te zwierzęta nie mają przecież nic wspólnego. Taka postawa wydaje się dość typowa - zabawnym przykładem nikłej wiedzy o tych stworzeniach wśród humanistów są scholia przekazane przez niemieckiego uczonego Arthura Ludwicha, które uznaja katalog pożywienia żab za prawdziwy i przez to pouczający dla młodzieży ${ }^{22}$.

$Z$ pozoru wydawałoby się, że można śmiało mówić o odnoszeniu tekstu do realiów rodzimych i współczesnych autorowi przekładu także z tego powodu, że rezygnuje on $z$ wielu istotnych nawiązań do Homera i mitologii. Zamiast powtarzanej w poemacie znanej formuły epickiej o purpurowych falach decyduje się na zwykłe słowo „woda”. Znacznie skraca też scenę porwania Europy przez Jowisza. Pomija przy tym fakt, że bóg dokonał tego pod postacią białego byka. W zasadzie jednak całą sytuację przedstawia tak, jakby Jowisz w ogóle nie ukazał się jako zwierzę, skoro nimfa została „uwiedziona słowy”. Poeta postępuje nie tylko wbrew greckim wersjom tego mitu, których znać nie mógł, ale też wbrew dobrze przyswojonym wersom Metamorfoz Owidiusza i oczywiście wbrew wszystkim łacińskim przekładom Batrachomyomachii. Nie mogło zatem dojść do żadnej pomyłki. Zapewne jest to kapitulacją, ale można jedynie przypuszczać, że taki obraz nie odpowiadał wrażliwości poety. Mimo wszystko wydaje się, iż celem Zaborowskiego nie było zupełne uwspółcześnienie poematu m.in. przez usunięcie nawiązań do greckiej literatury. Inaczej nie mógłby w drugiej części utworu dodać od siebie nie występujących w Batrachomyomachii porównań homeryckich, które musiał uznawać za rzecz najbardziej charakterystyczną dla epiki.

Tak np. w wersach 305-308 (PZ, s. 10) polski tłumacz porównuje starcie wojsk do dwóch drzew, które uderzają o siebie w wyniku wichury - jest to czytelne odwołanie do XVI ksiegi Iliady:

\footnotetext{
Tak jak wichrzyska dwa, Euros i Notos, zewrą się wzajem W górskich wąwozach i leśną głębinę tchnieniem przeorzą, Dęby, jesiony, derenie gęstoliściaste rozwichrzą, Tak że wzajemnie poplączą swoje rozchwiane ramiona Z szumem ogromnym i słychać trzask połamanych gałęzi _ ${ }^{23}$
}

Z kolei gdy opisuje natarcie mysz na żaby w wersach 479-483 (PZ, s. 16), porównuje te pierwsze do psów, które podczas polowania gonią zające i których nie sposób zatrzymać ${ }^{24}$. Taki obraz znamy z X księgi Iliady:

Zob. Die homerische „Batrachomachia” des Karers Pigres nebst Scholien und Paraphrase. Hrsg. und erläutert von A. Ludwich. Leipzig 1896, s. 198. 
[...] a tamci w pościg ruszyli $z$ zapałem.

Jak ostrozębe myśliwskie dwa psy do łowów ćwiczone

Gnają z wytrwałym uporem zająca albo jelenia

W leśnych pustkowiach, a zwierzę becząc przed nimi ucieka, ${ }^{25}$

Pojawiają się również porównania homeryckie wzorowane na Iliadzie delikatniej. Tak jest w przypadku wersu 277, gdzie poeta pisze: „Jako gdy wiatrem rannym ocean bieleje” (PZ, s. 9). Widać w tym echo powtarzającego się wielokrotnie u Homera obrazu wiatru i zazwyczaj wzburzonych wód, przy czym w pierwowzorze ton zawsze przybiera ciemne barwy ${ }^{26}$, a Zaborowski konsekwentnie usuwał w swoim przekładzie jej dość mroczny, purpurowy kolor. Dość ogólne nawiązanie można dostrzec również w wersach 367-370 (PZ, s. 12), zawierających porównanie do lwa rzucającego się ze skały na byka. Trudno wskazać w tym wypadku konkretne miejsce w Iliadzie; Zaborowski odnosi się raczej w sposób ogólny do postaci króla zwierząt, z której korzystał aojda, opisując wielkich herosów, takich jak Menelaos, Diomedes czy Hektor. Polski tłumacz stworzył też zupełnie indywidualne porównanie, zestawiając śmierć bohatera ze zniszczeniem przez wichry statku i zatopieniem jego skarbu, co u Homera jest niespotykane.

Zaborowski nie ograniczył się do środków stylistycznych charakterystycznych dla greckiej epiki, dodawał od siebie również elementy związane z mitologią. Dobrze pokazuje to scena przedstawiania się Psicharpaksa i Fysignathosa, jeden z jaśniejszych punktów zarówno greckiej, jak i polskiej Batrachomyomachii. Poeta nie próbował w żaden sposób oddać tak docenianej przez renesansowych humanistów gry słów widocznej w imieniu ojca Fysignathosa - a chyba musiał zdawać sobie sprawę z jej istnienia, skoro żart został wyjaśniony we wstępie Glareanusa poprzedzającym przekład Münsingera ${ }^{27}$. Być może dowcip wydawał mu się zbyt blady i dlatego ród żaby wywiódł od Cerbera, a ściśle rzecz biorąc: od jego śliny, która wpadła do bło$\mathrm{ta}^{28}$. Z mitów wiadomo, że $\mathrm{Z}$ wydzieliny monstrum miał wyrosnąć po zetknięciu się z ziemią silnie trujący kwiat - tojad, zwany pospolicie mordownikiem. Wybór Zaborowskiego wydaje się celny i spójny, ponieważ także niektóre płazy, np. licznie w Polsce występująca ropucha szara, mogą być dzięki swoim gruczołom jadowym nieco szkodliwe. Ponadto w zestawieniu Fysignathosa $\mathrm{z}$ jego przodkiem, straszliwym potworem (w dodatku nie trój-, lecz stugłowym ${ }^{29}$ ), tkwi wielki potencjał komiczny wynikający ze sparodiowania tradycyjnej epickiej przesady przy charakte-

twem niezręczności poety, czy też świadomym komicznym zabiegiem. W tekście nie ma dowodów na żadną z tych dwóch możliwości, ale przyjmujemy, że to żart, skoro w oryginale znalazło się miejsce na parodię bajki o dwóch myszach, miejskiej i wiejskiej, w postaci dyskusji Psicharpaksa i Fysignathosa o ich pożywieniu.

25 Ibidem, s. 237, w. 360-363.

26 Jasna, przejrzysta woda służy u Homera tylko do kapieli.

27 Zob. H. Glareanu s, wstęp w: JM, s. [4]: „chciał [autor] wyśmiać tak wielki wysiłek wojenny Greków. Dlatego zmyślił imiona wodzów stanowiące oczywiste szyderstwo z dowódców, np. Peleiona, imię żaby - [zaczerpnął je,] rzecz jasna, nie od syna Peleusa, chociaż to jońska forma patronimiczna, ale od tego, że buduje gniazdo w błocie". 
ryzowaniu herosów. Na marginesie trzeba też wspomnieć, że Zaborowski miał chyba pewne upodobanie do opisywania potworów, o czym świadczyłby również obraz węża morskiego, bardziej rozbudowany i straszniejszy niż w oryginalnej $\mathrm{Ba}$ trachomyomachii i jej łacińskich przekładach ${ }^{30}$.

Postępowanie Zaborowskiego jawi się często jako nie do końca konsekwentne; dowodem na to jest jego wersja bitwy żab z myszami. Bywa, że w ogóle nie podaje on imion bohaterów - np. zamiast opowiedzieć o pierwszej parze wojowników, którymi są Hypsiboas i Leichēnoras, pisze ogólnie: „ktoś oszczepem szumnego / Doworę dosięgł” (PZ, s. 10, w. 293-294). Rezygnuje z przedstawienia walki, w której uczestniczą Seutlaios, Embasichytros, Artofagos i Polyfōnos, i stwierdza tylko krótko: „kilka osób poległo” (PZ, s. 10, w. 301). Ogranicza się do wzmianki: ,jeden bez litości / Zdziera $z$ drugiego" (PZ, s. 11, w. 345-346), a nie informuje, że padł Limnisios i że Tyroglyfos zabrał mu zbroję. Czasem jest na odwrót - Zaborowski podaje imię postaci, ale nie ma ona żadnego odpowiednika w źródłach przekładu (dotyczy to np. Borysołama).

Zdarzają się jednak i wierne opisy, gdzie nawet kolejność wydarzeń odpowiada źródłom poety. I tak Trōglodytēs wypuszcza włócznię, a od niej ginie Pēleiōn, u Zaborowskiego sa to kolejno Łuszcz i Zaligon. Kalaminthios porzuca tarcze, gdy widzi, że zmierza ku niemu Pternoglyfos - w przekładzie chodzi o Kwokota i Chrobota. Zgadza się też brutalna scena, w której Pternofagos umiera po tym, gdy Hydrocharis powalił go uderzeniem w tył głowy - Zaborowski czyni ją nawet okropniejszą, przekazując, że Szerstenorze od ciosu Gołobrzucha wypłynął mózg. Poeta równie dokładnie opisuje, jak Psicharpaks ciska głazem, od czego ranny zostaje Pēlobates (w tłumaczeniu Wiedoł kruszy goleń Pstrocinie), albo jak spływają wnętrzności tego pierwszego po zemście, której dokonał na nim Kraugasidēs, czyli Jezioromok.

Niektóre $\mathrm{z}$ dokładnie przełożonych passusów różnią się u Zaborowskiego tylko zamienionymi postaciami - jak wtedy, gdy Limnocharis zabija uderzeniem w szyję znanego nam już Trōglodytēsa (w przekładzie sa to Jamor i Błotoryj) albo gdy Leichēnorasowi wylatują wnętrzności (odpowiednio: Wiedłowi). Warto zauważyć, że sa to akurat te postacie $\mathrm{z}$ łacińskiego przekładu, które Zaborowski zupełnie pominął, zastępując ich działania ogólnymi opisami. Dlaczego tak postapił? Najpewniej odpowiadały mu ich waleczne czyny, ale wiele kłopotów przysporzył fakt, że Leichēnoras i Trōglodytēs zmartwychwstają, co ma być żartem autora Batrachomyomachii bazującym na sentencji „aliquando bonus dormitat Homerus”, który Zaborowski najwidoczniej przeoczył. Dlatego też, wbrew oryginałowi, nie ożywił utopionego Psicharpaksa (w jego przekładzie: Syrogryza), tylko wprowadził poprawki. machii, kierując się wzorcami poezji rzymskiej. Nawiązał do obrazu węża zmierzającego ku Laokoonowi z II księgi Eneidy (por. ,po wierzchu wody cichej piersi okazałe wydawszy” 〈PZ, s. 4, w. 111$112\rangle$ - „pectora quorum inter fluctum arrecta iubaeque / sanguinae superant undas”; „oczy jadem pałaja” 〈jw., w. 115〉 - „ardentisque oculos”; ,język u gęby mikce” 〈jw., w. 116〉 - „linguis vibrantibus"), ale i do zawartego w pieśni I 22 Horacego (Integer vitae) opisu wilka, który badacze uznaja za heroikomiczny (por. „wierzę, w żadnym lesie / Takiego mysz strapiona przed tym nie widała” 〈jw., w. 116-117〉 - „Namque me silva lupus in Sabina, / [...] / fugit inermem, // quale portentum neque militaris / Daunias latis alit aesculetis"). Lepszych źródeł polski poeta znaleźć chyba nie mógł. 
Oczywiście jest też możliwe, że zrezygnował z dowcipu, obawiając się, by nie został on wzięty za jego własną pomyłkę.

Jeśli chodzi o same imiona bohaterów, łatwo zauważyć, że nieczęsto odpowiadają pierwowzorom. Czerniatowicz słusznie stwierdziła, że część z nich wprawdzie Zaborowski oddał dokładnie (Pternotrōktēs - Połciorad, Borborokoitēs - Błotoryj, Fysignathos - Skrzeczołóg), w wielu wypadkach trudno jednak znaleźć jakiekolwiek podobieństwo (Sitofagos - Kawrun, Kalaminthios - Kwokot, Trōglodytēs - Łuszcz, Leichopinaks - Gołogon etc.), a nawet wskazać na źródło w oryginale (co dotyczy wspomnianego już Borysołama, jak też Wiedoła i Ziemiozra) ${ }^{31}$.

W przekładzie Zaborowskiego można dostrzec także pewne posunięcia niezależne już od decyzji dotyczących tłumaczenia, a wynikające ze znajomości ówczesnej literatury. Na pewno jest to upodobanie do szczegółów. Nie brakuje ich zwłaszcza, gdy mowa o rzeczach pięknych i wartościowych. Dary przeznaczone dla Psicharpaksa są w oryginale przedstawione bardzo ogólnie, u Zaborowskiego zaś zostały skonkretyzowane, chodzi mianowicie o drogi klejnot. Poeta dodaje też od siebie cały opis przedstawiajacy pałac Fysignathosa położony pod Troją: wspomina przy tym kosztowny miecz, złoty hełm, marmurowe ściany. Wersja grecka i łacińska są bez wątpienia bardziej oszczędne niż polska.

Innym takim aspektem jest uleganie nakazom retoryki. Choć rozbudowane mowy to cecha charakterystyczna eposu - czego najlepszym przykładem IX księga Iliady - nie ma ich zbyt wiele w Batrachomyomachii, a przy tym są dość zwięzłe. Zaborowski je rozwija. Czasami czyni to bardzo zręcznie, choćby w momencie, gdy ojciec Psicharpaksa zwołuje zgromadzenie i chce przekonać myszy do wypowiedzenia wojny. W polskim przekładzie znajduje się znacznie większa liczba argumentów: Zaborowski powołuje się na szacunek należny starszym ludziom, współczucie wobec przedstawicieli tego samego gatunku czy możliwość uzyskania sławy. Zdarzają się też mniej trafne decyzje, np. znaczne wydłużenie ostatniej wypowiedzi topiącej się myszy (choć długie przemowy herosów w chwili śmierci są zgodne z epicką konwencja), uzyskane głównie przez wprowadzenie inwokacji do kolejnych bóstw mogących zemścić się na Fysignathosie - 16 wersów zamiast 5 wersów w oryginale to odrobinę za dużo. Ta zmiana świetnie obrazuje tendencję Zaborowskiego do rozszerzania monologów i dialogów kosztem narracji. Widać ją także w uzupełnianiu działań bohaterów o krótkie wypowiedzi, takie jak: „i ty idź z drugim, a nie bądź ociętny” (PZ, s. 11, w. 332) albo „Nie wygracie, / Odejmę wam tę próżną chwałę, którą macie” (PZ, s. 13, w. 389-390) - w oryginale bohaterowie nie odzywają się do siebie podczas walki. Milczenie to akurat nie dziwi, skoro bitwa zajmuje tam zaledwie 70 wersów i nawiązuje do partii Iliady pozbawionych takich wstawek, ale Zaborowskiemu, jak widać, zależało na urozmaiceniu utworu, przez co znacznie go też wydłużył.

Nie sposób wreszcie przeoczyć dydaktyzmu ujawniającego się w polskiej Batrachomyomachii, co jest rzeczą dość nietypowa dla heroikomiki, biorąc pod uwage fakt, że jeśli doszukiwano się w utworze wartości moralnych, to tylko w krytyce wojny. U Zaborowskiego narracja pełna jest rozmaitych komentarzy dotyczacych 
działań bohaterów. Gdy ginie Łuszcz, poeta pozwala sobie na ogólną myśl dotyczącą losu („Ach, niedługo drugiemu coś wziął, toś sam stracił”, PZ, s. 10, w. 313), a następnie dowodzi, że postaci zabrakło wielu rycerskich cnót i że zginęła $z$ chciwości, podobnie jak Hektor, który sięgnął po zbroję Achillesa, co jest oczywiście bardzo dyskusyjnym stwierdzeniem. Krytykę braku umiarkowania spotykamy także później, choćby w wersach 345-346 (PZ, s. 11), gdy dowiadujemy się, że herosi o mało co nie zdzieraja $\mathrm{z}$ drugich skóry.

Zaborowski stworzył dzieło bardzo odmienne od oryginalnej Batrachomyomachii, zasługujące raczej na miano parafrazy niż tłumaczenia. Usunął elementy, które były ważne dla antycznych odbiorców - takie jak nawiązania do Kallimacha albo żarty bazujące na scholiach do Homera. Wynika to $\mathrm{z}$ braku filologicznego podejścia do przekładu, a także $z$ faktu, iż $w$ czasach autora polskiego przekładu wiedza o literaturze hellenistycznej była nikła i nikt nawet nie podejrzewał, że Batrachomyomachia jest utworem $z$ tak późnej epoki. Zaborowski nie postępował konsekwentnie, wiernie oddał losy jedynie części postaci i tylko niektóre $z$ ich imion przetłumaczył dokładnie, opierając się na swoich źródłach. Zadbał jednak o rzetelne przekazanie wszystkich elementów właściwych heroikomice, a nawet dodał od siebie kilka nie występujących $\mathrm{w}$ oryginale porównań homeryckich, powszechnie uznawanych za charakterystyczne dla epiki. W jego przekładzie odcisnęły się wyraźnie takie ówczesne tendencje literackie, jak nacisk na retorykę i dydaktyzm oraz upodobanie do szczegółów. Wrażenie to wzmacnia jeszcze dostosowywanie Batrachomyomachii do ówczesnych realiów. Nie można jednak odmówić Zaborowskiemu pewnego indywidualnego pierwiastka widocznego choćby w opisach straszliwych monstrów, rzeczy zasadniczo nie występującej w oryginale, ale dobrze wpisującej się $\mathrm{w}$ parodystyczną konwencję, i w zręcznym włączaniu do poematu motywów z literatury łacińskiej, które nakładają się na siebie i które w związku z tym trzeba odczytywać równolegle - zupełnie jak w wypadku znakomitej w oryginale sceny spotkania Psicharpaksa i Fysignathosa. Wreszcie nie należy zapominać, że była to trzecia w Europie próba przełożenia Batrachomyomachii na język narodowy ${ }^{32}$, i chyba nie najgorsza.

\author{
Abstract \\ JAKUB ZBĄDZKI University of Wrocław \\ ORCID: 0000-0002-6268-5469
}

\title{
“BATRACHOMYOMACHIA" IN PAWEE ZABOROWSKI'S VERSION INTRODUCTORY REMARKS
}

The article acts as a presentation of Paweł Zaborowski and as an analysis of Batrachomyomachia in his translation published in the year 1588. Two Latin texts that could have been sources of the Polish translation, namely an anonymous line-for-line translation and a verse translation by Joachim Münsinger, are indicated. The paper discusses the original features of Zaborowski's piece that make it different from the other $16^{\text {th }} \mathrm{c}$. Latin translations of the text and from the Greek original, i.e. adjusting it to the reality contemporary to the poet, supplementing it with epic elements (as Homeric similes), adhering to the principles of rhetoric, didactism, as well as referencing to Roman poets. 